\title{
Increased Eroded Surface
}

National Cancer Institute

\section{Source}

National Cancer Institute. Increased Eroded Surface. NCI Thesaurus. Code C147496.

An increase in the amount of surface erosion. 